California's breathtaking natural attractions are not the only stars on the Central Coast. Equally impressive are the top-trained medical professionals at Natividad Medical Center, a state-of-the-art 172-bed teaching hospital with a JCAHO ranking in the top percentile of hospitals nationwide. When you bring your nursing career to Natividad, you'll join a facility that is affiliated with the University of California San Francisco and that has the area's only Life-Flight helicopter service, as well as one of the County's first Community Level III NICUs. As a member of the Natividad team, the sky's the limit, for you and your career.

\title{
Infection Control Nurse
}

We currently seek an experienced RN to coordinate all infection control activities for the hospital, including staff education in the prevention and control of infection and investigation of suspected infectious outbreaks. We'll rely on you to review patient charts and the hospital for compliance to infection control standards and prepare mandated documentation forms. This key assignment requires a CA-licensed RN with a working knowledge of aseptic procedures in a hospital setting, medical terminology, etiology and treatment of infectious disease.

As a member of our cohesive team, you'll enjoy extremely competitive salaries and an excellent benefits package, including $100 \%$ paid CALPERS retirement. For application materials, contact Natividad Medical Center, Human Resources, 1441 Constitution Blvd., PO Box 81611, Salinas, CA 93912-1611; call us at (831) 755-4282; or apply online at www.natividad.com. Natividad Medical Center is committed to employing a diverse workforce. EOE/M/F/H/V

\section{AM Natividad MEDICAL CENTER}

on California's beautiful Central Coast.

Unique views on the Central Coast.

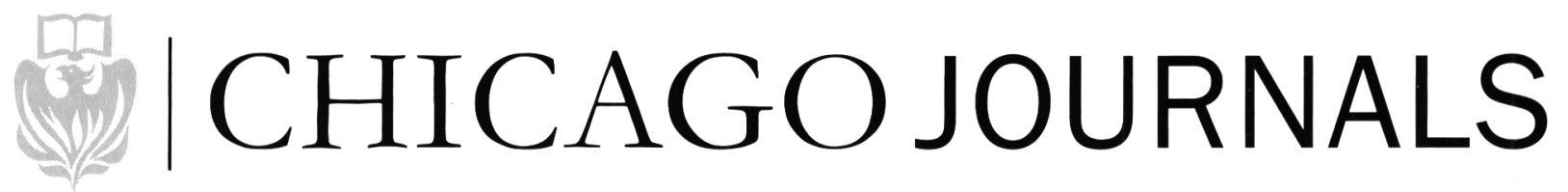

\section{SOCIAL SCIENCES}

The American Historical Review American Journal of Sociology Crime and Justice

Current Anthropology

Economic Development and

Cultural Change

Isis

Journal of British Studies

Journal of Consumer Research

Journal of Human Capital

Journal of Labor Economics

The Journal of Law \& Economics

The Journal of Legal Studies

The Journal of Modern History

Journal of Political Economy

The Library Quarterly

National Bureau of Economic

Research Annuals

Innovation Policy and the Economy

NBER International Seminar on

Macroeconomics

NBER Macroeconomics Annual

Tax Policy and the Economy

Osiris

Philosophy of Science
Signs

Social Service Review

Supreme Court Economic Review

The Supreme Court Review

HUMANITIES

American Art

Classical Philology

Critical Inquiry

Ethics

History of Religions

International Journal of American

Linguistics

Journal of Near Eastern Studies

The Journal of Religion

Modern Philology

Signs

Winterthur Portfolio

\section{PHYSICAL SCIENCES}

The Astrophysical Journal

The Astrophysical Journal

Supplement Series

The Journal of Geology

Publications of the Astronomical

Society of the Pacific

\section{EDUCATION}

American Journal of Education Comparative Education Review The Elementary School Journal

\section{BIOLOGICAL AND HEALTH SCIENCES}

The American Naturalist

Clinical Infectious Diseases

Infection Control and Hospital

Epidemiology

International Journal of Plant Sciences

The Journal of Infectious Diseases

Physiological and Biochemical

Zoology

The Quarterly Review of Biology 


\section{THE SOCIETY FOR HEALTHCARE EPIDEMIOLOGY OFAMERICA}

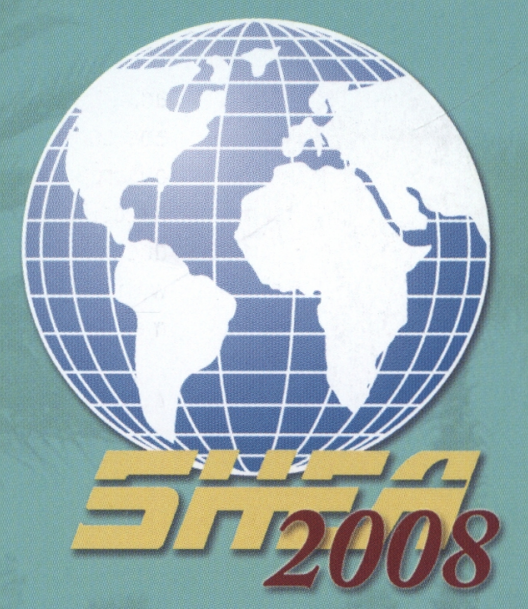

APRIL 5 - 8, 2008

BUENA VISTA PALACE

ORLANDO, FLORIDA

M

embers of the field of infection prevention and control face the challenges of merging science with cost containment realities, adapting to local and federal pressures, and staying on top of emerging issues. SHEA 2008 will bring together top clinicians, scientists, and practitioners to identify best practices, new technologies, and up-to-date advances to keep you on the forefront of patient care and healthcare worker safety.

\section{Registration is now open!}

Discounted pre-registration closes on Friday, February 1.

Pre-registration closes on Friday, March 7.

To register and to learn more about SHEA 2008, check SHEA's Annual Meeting site at: http://www.shea-online.org/about/annual_meeting_overview.cfm

ye TाIIIIIIIIIIIII 


\section{The Value is in the Clarity...}

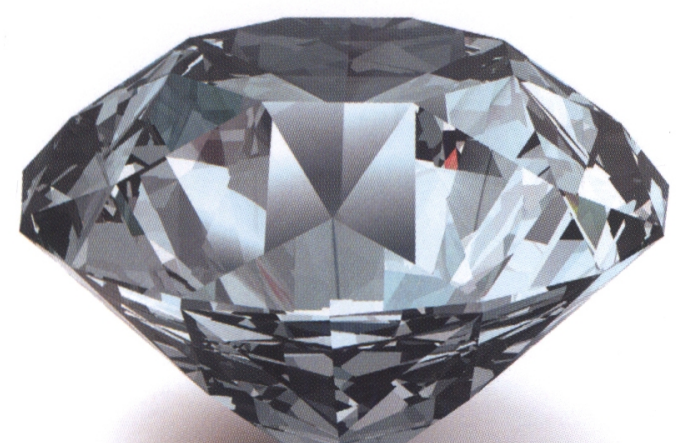

\section{Introducing the First and Only Clear Positive Displacement Connector}

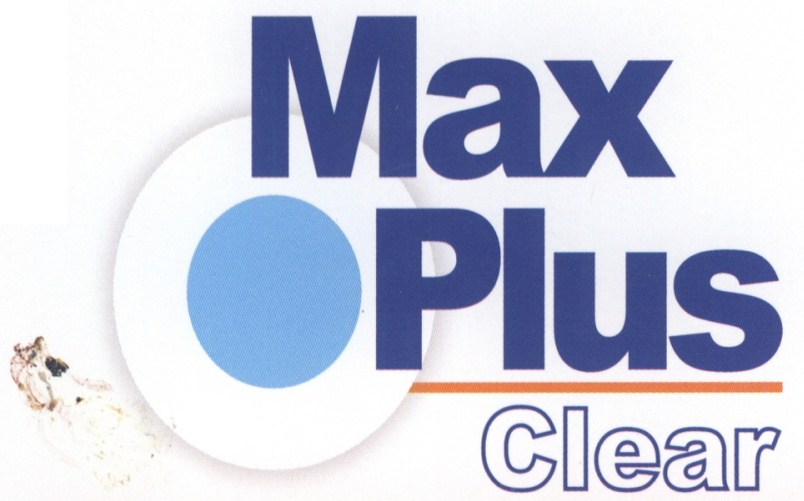

\section{MaxPlus $₫$ Clear ${ }^{\top M}$...the value is in the Clarity!}

Connect with Confidence. MaxPlus Clear provides complete visualization of the fluid path providing a clear reminder to prime \& purge all air, disinfect better and flush completely. Clarity enhances practice, reducing the occurrence of bloodstream infections and occlusions. Thus, enhancing patient care.

\section{Visit us at the SHEA Conference Booth \# 226}

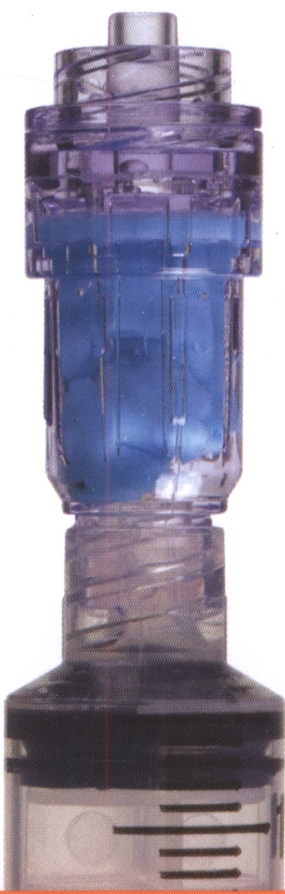

